\title{
A dupla chama ou o jogo da sedução em A dama e o unicórnio, de Maria Teresa Horta
}

\author{
Carlos Roberto dos S. Menezes \\ Universidade Federal do Rio de Janeiro
}

\begin{abstract}
Resumo
A partir das reflexões teóricas e filosóficas de Georges Bataille, O erotismo; Didi-Huberman, $O$ que vemos e o que nos olha; Octavio Paz, A dupla chama: amor e erotismo; Gilda Santos e Horácio Costa, $A$ poética dos cinco sentidos revisitada; Cleonice Berardinelli, "Mon seul désir", entre outros, o presente artigo busca relacionar a obra $A$ dama e o unicórnio, de Maria Teresa Horta, com as tapeçarias medievais quatrocentistas La Dame à la licorne.
\end{abstract}

Palavras-chave: Adama e o unicórnio; Maria Teresa Horta; erotismo; transgressão; poesia contemporânea portuguesa.

\begin{abstract}
From the theoretical and philosophical reflections of Georges Bataille, O erotismo; Didi-Huberman, O que vemos e o que nos olha; Octavio Paz, A dupla chama: amor e erotismo; Gilda Santos e Horácio Costa, A poética dos cinco sentidos revisitada; Cleonice Berardinelli, "Mon seul désir", among others, the present article seeks to relate the work $A$ dama e o unicórnio by Maria Teresa Horta with the medieval tapestries of the fourteenth century La Dame à la licorne.
\end{abstract}

Keywords: the lady and the unicorn; Maria Teresa Horta; eroticism; transgression; Portuguese contemporary poetry.

Recebido em: $12 / 06 / 19$

Aprovado em: 29/06/19

E agora, eu que a todos vos interrogo e que procuro a tua

imagem no tapete... Não essa, visivel, a fingir que não vê e cheira. Não a outra, invisivel de quem segurou nas mãos os fios que te criaram. Esta, a que eu lá pus através da teia de palavras que no papel vou alinhando, palavras que não cheiram também, nem veem, nem ouvem, nem sequer são de lã e de seda. Palavras que também nada significam, são somente para ser lidas.

Augusto Abelaira

Recorremos a um autor próximo, deveras conhecido, cujas palavras soam como uma espécie de conforto, um caminho já percorrido; no entanto, cada linha revisitada da sua obra ainda 
esconde um mistério, uma inquietação capaz de nos despertar o assombro e a comoção: Augusto Abelaira, autor da epígrafe deste texto, que surge como um meio para que possamos adentrar um bosque ainda desconhecido. Recortamos esta passagem de "O olfacto" (ABELAIRA, 2010), pois, há numa precisão textual, alguns dos principais elementos com os quais pretendemos tecer este texto. Retomando a epígrafe, o narrador está à procura de uma imagem que se encontra retida num tapete. Uma imagem criada por alguém, que transcende o trabalho artesanal da tessitura com lã e seda e a transporta para a linguagem. Uma imagem em palavras "que também nada significam, são somente para ser lidas", simulacros, fingimentos: signos vazios. ${ }^{1}$

O conto de Augusto Abelaira revisita a tapeçaria Tenture de La Dame à la licorne: l'Odorat. E é precisamente sobre ela que pretendemos nos debruçar. Mais do que visitar as tapeçarias e seus mistérios, estaremos acompanhados de um olhar que procurou na sua inquietação ressignificar a imagem diante dos olhos, melhor dizendo, recompôs a imagem da Dama numa outra tapeçaria, não mais de lã e seda, mas sim de palavras subentendidas e existentes nas entrelinhas do texto, tal qual fez Abelaira.

Antes, contudo, para aqueles que não estão familiarizados com a exuberância da tapeçaria acima referida nos cabe uma breve apresentação. La Dame á la licorne é o título atribuído, a partir do século XIX, ao conjunto de seis tapeçarias francesas consideradas como um dos grandes trabalhos da arte medieval na Europa. Estima-se que tenham sido compostas no final do século XV ou início do século XVI. Presume-se que a "tenture" representa uma alegoria dos cinco sentidos (olfato, audição, tato, paladar, visão) e mais um denominado "Mon Seul Désir" — talvez a representar o sexto sentido do entendimento.

A obra de autoria anônima tem duas possíveis interpretações da sua criação: a primeira diz respeito ao fato de terem sido feitas para Claude Le Viste, quando noiva de ChabannesVendenesse, irmão do Marechal de La Palisse; outra possível versão é a de terem sido encomendadas por Jean Le Viste, pai de Claude. Contudo, tais questões pouco interferem na interpretação desta grande obra medieva, exceto pela decodificação das três luas que aparecem nos brasões que estão presentes em todas as peças e dizem respeito à família Le Viste.

Expostas no Museu de Cluny, em Paris, desde 1882, essas tapeçarias suscitam diversas leituras e requerem de seus admiradores uma viagem através dos seus mistérios. Viagem esta percorrida, por exemplo, por seis autores portugueses: Ana Hatherly, Augusto Abelaira, Isabel da Nóbrega, José Saramago, Maria Velho da Costa e Nuno Bragança, que se lançaram na tarefa de desbravarem os enigmas e significados ou ressignificarem as imagens das tapeçarias através das palavras - a imagem que esses autores procuram nos tapetes de La Dame à la licorne encontra-se organizada no livro Poética dos cinco sentidos (1979). ${ }^{2}$

\footnotetext{
${ }^{1}$ Ao contrário de Augusto Abelaira, Maria Teresa Horta ressignifica as imagens em alguns de seus versos transmutando-as e revertendo seus enigmas.

2 Trinta anos depois (2010), Gilda Santos e Horácio Costa revisitam a obra anteriormente publicada pela Editora
} 
Entretanto, embora um dos textos que compõe o volume referido nos sirva de epígrafe e esteja nos auxiliando no início desta nossa excursão, não é sobre os textos de Poética dos cinco sentidos que iremos tratar, mas, sim, de uma outra revisitação das tapeçarias feitas pelas mãos de Maria Teresa Horta, autora portuguesa contemporânea, cujas palavras buscam retratar a fisicalidade do corpo, do sexo, do erotismo e, principalmente, das questões que envolvem o feminino.

Lançado em outubro de 2013 pela editora Dom Quixote, A dama e o unicórnio, vem a público numa edição primorosa recheada de imagens e fragmentos das tapeçarias de La dame à la licorne, acompanhada de um CD com a "cantata profana" de António de Souza Dias e recitação dos poemas por Ana Brandão. Através de uma escrita erótica e feminista, Maria Teresa Horta revisita as tapeçarias e recria poeticamente uma narrativa que ressignifica a imagem da Dama e do Unicórnio que outrora ficou retida em seus olhos.

A dama e o unicórnio abre-se com uma premissa que parte do jogo da sedução entre as duas personagens centrais presentes nas tapeçarias medievais: a Dama e o Unicórnio. O tom erótico é bordado nas páginas do livro a partir da proposição: “A dama seduz/ Ou o unicórnio entrega-se?”; “No jogo da sedução/ Quem usa a taça e a seta?”. ${ }^{3}$ Através do jogo estabelecido o poetar pensante da autora irá, por meio da linguagem, recompor as seis tapeçarias, fragmentando as imagens para a plasmação de um corpo poético que encena uma trama sob o jogo da sedução. $\mathrm{O}$ tecer da palavra se perfaz por meio de um mosaico que, paulatinamente, vai sendo mostrado em forma de imagem e recriado por meio da linguagem.

A original interpretação das tapeçarias faz com que a obra poética de Maria Teresa Horta se desdobre em momentos de composição que, por vezes, refletem o próprio fazer poético. Os 72 poemas se dividem nos seguintes enquadramentos: «Arte e Ofício», «As Personagens», «As Tapeçarias», «O Mito», «À mon seul désir», «A Sedução», «Posse» e «A Eternidade». Cada enquadramento é precedido ou antecedido por outros denominados de «Ad limina» "ad" = para, aproximação, direção para, o começo de uma ação; "līmen, īnis", substantivo = limiar, soleira de porta, e entrada, casa, morada; sentido figurado: princípio, começo; sentido poético: barreira (nas corridas - Vergílio, "Eneida") - que funcionam como uma espécie de finalização da parte anterior e de introdução da subsequente, uma vez que "tais grupos realizam um escrito poético paralelo, com índole crítica, informativa ou explicativa acerca dos blocos adjacentes" (DAL FARRA, 2016, p. 299).

Bertrand (1980) e reorganizam o volume acrescentando seis ensaios críticos redigidos por estudiosos brasileiros de literatura incumbidos de se debruçarem sobre um dos textos que compõem a poética dos cinco sentidos. Nesta empreitada surge pelo selo da Editora 7Letras o livro: Poética dos cinco sentidos revisitada.

${ }^{3}$ Para fins de citação referentes aos poemas e versos que compõem os poemas de $A$ dama e o unicórnio, de Maria Teresa Horta, deve-se levar em consideração a primeira edição publicada pela editora Dom Quixote, haja vista que o livro não tem numeração de página. 
O «enredo» é construído por meio do "nó", "do novelo", "a tecer/ a história a ser-nos contada" "com o fio/ com a linha/ com a lã inglesa", das misturas de cores entre o azul, o vermelho, o anil, entrelaçando os "segredos" "na trama narrando o que fica calado". O trabalho descrito parte do gesto da artesania de composição de uma tapeçaria cujo bordado, os fios, a lã e a seda dão lugar às palavras, às rimas, às métricas, aos versos e às estrofes. A poeta torna-se a artesã da sua escrita que na "ausência do gume/ onde o fio se entreteça/ sendo a sedução uma arma afiada".

O corpo feminino adquire desde o início protagonismo da cena tecida poeticamente, isto porque em «Arte e Ofício» o primeiro poema faz uma invocação às tecedeiras, tintureiras e fiadeiras. São essas personagens que vão desenredar o feitiço "em que o Unicórnio se sujeita", em outras palavras o "desejo", "ao enriço/ de uma única Dama” para que a lã e a seda acabem e a palavra poética principie.

Em seguida, nos é descrito todo o processo de composição das tapeçarias. Processo este que não só recupera a artesania manual do desenho a carvão: "torna-se invisível/ debaixo das lãs, dos fios e das linhas" por meio dos bordados, como nos é transposta de forma paralela a própria artesania verbal, descortinando a filosofia da composição por detrás do enredo que se perfaz aos olhos do leitor ao ver as imagens se transformarem em linguagem.

A Dama, enquanto objeto de criação, fica parada "no desenho e no pincel/ antes de ser desenhada/ depois tecida e fiada" e, por último, escrita, descrita, inscrita nas malhas do texto. Os dedos em harmonia bordam tapeçaria e poema, "desdizendo/ desvendando/ todos os segredos" da intriga "onde a urdidura seduz/ deixando passar na trama/ a lançadeira dançante". É por meio das fendas, das aberturas, dos detalhes do bordado que "os desejos calcinados/ os prazeres resguardados" vão sendo descortinados ao ponto de a Dama "grita[r] de gozo".

Eis como os objetos do plano material (oficina, tear, lã, agulha, tinta, bobinas, artesãs, artistas, pontos de bordado, desenhista, talagarça, etc.), daquilo que diz respeito ao "entrançamento" da tapeçaria, do seu universo infra-estrutural, passam a se cruzar e a conviver com os materiais do nível da "urdidura" da tela. Ou seja: com os seres, os objetos, os animais e as vegetações do enredo, bem como com todos os estratos sócioculturais e míticos que foram se apensando aos quadros ao longo dos séculos — trâmite que alcança até mesmo a escrita dos poemas. (DAL FARRA, 2016, p. 300)

Podemos dizer que $A$ dama e o unicórnio é um livro que se pensa, que é pensado e busca pensar a relação entre arte e escrita, entre a tapeçaria e a poesia. A escrita nos surpreende exatamente pela constante apreensão do próprio trabalho de composição e tessitura dos temas abordados numa trama que oscila entre poema e metapoema, num jogo em que a personagem seduz, é seduzida, mas que também o trabalho da escritura acaba por seduzir o leitor. Concordamos com Maria Lúcia Dal Farra quando nos diz que 
A poesia se torna, então, trabalho manual de desenredamento, de desconstrução, de desocultação e de reorganização dos materiais anteriores, e, para o caso - tanto dos componentes das tapeçarias quanto daqueles do poema. De maneira que a obra de Horta vai, assim, localizando agudas visões sobre a condição da mulher, interrogando sobre o comportamento dos gêneros, ao mesmo tempo que, metalinguisticamente, se põe buscando dar conta daquilo que vai produzindo pouco a pouco. Já se vê que é nessa agitação interna que a Dama ganha vida própria. (DAL FARRA, 2016, p. 300)

É no movimento em que o dedo tropeça na linha que a oficina da escrita vem à cena por meio da primeira «Ad limina», demonstrando o «sequestro» que a escritura faz da imagem das tapeçarias no jogo de (re)significação no corpo poético. Poema e imagem, linguagem e metalinguagem, tema, tessitura e trama são pensados criticamente:

\author{
Desde quando a imagem \\ é jogo? \\ de sedução? \\ E a sedução \\ é sequestro? \\ E a poesia de mão \\ se confunde \\ com a rosa \\ espinhosa \\ no coração?
}

O pintor é chamado à cena, pois ele também se torna um personagem desta história. É por meio do carvão e do pincel que as tapeçarias começam a tomar forma, antes que as linhas, lãs e sedas apaguem os desenhos e aprisionem seus personagens na eternidade da bordadura.

No fluir da construção textual, surgem em cena «As personagens» que dão vida à trama. Num movimento de desvendar o mistério advindo da multiplicidade da expressão facial que a Dama apresenta ao longo das tapeçarias, Maria Teresa Horta faz uso da ambivalência que a Dama possui ao ser trançada nas tapeçarias: "O rosto da Dama difere", varia, "numa lenta/ mutação/ de belezas corrompidas", isto porque há um paralelo, um "verso-reverso" entre a Dama que, a princípio, é "apenas uma/ nesta história", mas que "nos desenhos do Pintor são duas": ora retrata a mãe, ora desenha a filha. Geneviève de Nanterre que representa a face mais madura, a malícia, enquanto Claude Le Viste "tem a alma de pouca idade/ e do corpo/ a finura da haste". "Face da filha alternando com a face da mãe". Na trama não é o Unicórnio que convoca aquela cujo desejo se mostra latente, mas é o artista seduzido pela beleza de ambas: "Ora dando à Dama o rosto/ da mais velha/ Ora adoçando-lhe os traços/com as feições 
da filha". A ambivalência da Dama que, ao ser retratada, reflete a sedução do artista diante da beleza de Geneviève e Claude, também reflete a sedução da poeta que se vê enredada no mistério deste jogo de verso e reverso. Contudo, o jogo não se encerra na representação entre mãe e filha, pintor e poeta, pois o corpo feminino que subverte a ordem imposta pelo imaginário medieval, transcende os tempos e evoca para o corpo narrativo dos poemas outras imagens que representam o próprio Eterno Feminino: Helena de Troia, Dalila, Medusa, Penélope, Artemísia, Eurídice, Alice, e, inclusive, aquelas cujas sobrevivências residem no anonimato, embora sejam necessárias pelo trabalho que exercem na artesania da composição artística: as tecedeiras, tecelãs, tintureiras e fiadeiras.

Entre o feminino, além da Dama - sempre a mesma? — há a presença de uma Aia em quatro das seis tapeçarias, e que também ocupa o estatuto de personagem em $A$ dama $e$ o unicórnio. Sempre em silêncio, delicada, os movimentos desta Aia estão subordinados aos desejos da Dama. É ela quem auxilia a sua ama, assim como é aquela que faz "a mediação dos mundos".

Dono de uma extremada brancura, surge em cena aquele que faz parte dos mitos: o Unicórnio. No imaginário da Idade Média, caçadores se utilizavam de virgens como isca para capturá-lo. Como aponta Mariana Ianelli (2014), a representação desta figura mítica foi ganhando novas configurações ao longo do tempo:

A abordagem de Richard de Fournival, do século XIII, é a primeira a inserir o episódio da caça ao unicórnio no contexto do amor profano e das armadilhas da conquista. Essa abordagem será retomada mais tarde, alternando os atributos de virilidade e de pureza e as dimensões do amor carnal e do amor divino ( $\mathrm{s} / \mathrm{p})$.

O unicórnio, por ser aquele que detém um único chifre em sua fronte, representa o poder, mas também designa o luxo e a pureza. Jean Chevalier e Alain Gheerbrant nos elucidam que

O unicórnio também simboliza, com seu chifre único no meio da fronte, a flecha espiritual, o raio solar, a espada de Deus, a revolução divina, a penetração do divino na criatura. Representa na iconografia cristã a Virgem fecundada pelo Espírito Santo. Esse chifre único pode simbolizar uma etapa no caminho da diferenciação: da criação biológica (sexualidade) ao desenvolvimento psíquico (unidade assexuada) e à sublimação sexual. O chifre único foi comparado a um pênis frontal, a um falo psíquico (VIRI, 202): o símbolo da fecundidade espiritual. (CHEVALIER e GHEERBRANT, 2009 , p. 919, grifos dos autores)

Pelas mãos da poeta, a figura mítica oscila entre a "inocência" e a "crueldade', sendo um ser "imponderável” e "impossível”, detentor do "poder/ da saúde eterna/ oculto nas rosas do seu sangue". 
Já a figura do leão que acompanha o bestiário presente na tapeçaria é autointerpretado pelos versos de Maria Teresa Horta:

\author{
O Leão simboliza o poder \\ o outro alquímico \\ Transporta consigo \\ o vigor e a coragem \\ Ele ergue as insígnias \\ do senhor seu amo \\ Marca o terreno \\ e vigia a caça \\ Animal solar \\ ele cumpre e enlaça
}

O Unicórnio simboliza a potência erótica, enquanto que o leão, por sua vez, comporta-se como um antagonista, sendo visto como um ser soberano, indomável, representante da vigília, da proteção e da manutenção do poder patriarcal:

Poderoso, soberano, símbolo solar e luminoso ao extremo, o leão, rei dos animais, está imbuído das qualidades e defeitos inerentes à sua categoria. Se ele é a própria encarnação do Poder, da Sabedoria, da Justiça, por outro lado, o excesso de orgulho e confiança em si mesmo faz dele o símbolo do Pai, Mestre, Soberano que, ofuscado pelo próprio poder, cego pela própria luz, se torna um tirano, crendo-se protetor. Pode ser, portanto admirável, bem como insuportável: entre esses dois polos oscilam suas numerosas acepções simbólicas. (CHEVALIER e GHEERBRANT, 2009, p. 538)

Em outras palavras, o leão configura a manutenção do poder por meio da força, como bem ilustram os versos citados acima: "Ele ergue as insígnias/ do senhor seu amo// Marca o terreno/ e vigia a caça".

A presença do leão nas tapeçarias funciona como uma alegoria do poder falocrata que passa a ser relativizado pela palavra poética de Maria Teresa Horta, quando permite que a Dama se torne senhora do seu desejo, sujeito da sua própria existência, tornando possível a sua compreensão do próprio corpo e sexualidade.

As personagens são entrelaçadas nas malhas da tessitura poética e passam a representar a trama regida, não mais pelas mãos do artista, do pintor ou das tecedeiras, mas pelos dedos da poeta que recria, refaz, reinventa a trama através da chama do desejo que julga nascer do interior da Dama. 
Octavio Paz apresenta uma definição da poesia através dos seus segredos e testemunhos, vejamos:

aquilo que nos mostra o poema não vemos com nossos olhos da matéria, e sim com os do espirito. A poesia nos faz tocar o impalpável e escutar a maré do silêncio cobrindo uma paisagem devastada pela insônia. O testemunho poético nos revela outro mundo dentro deste, o mundo outro que é este mundo. Os sentidos sem perder seus poderes convertem-se em servidores da imaginação e nos fazem ouvir o inaudito e ver o imperceptivel. (1994, p. 11, grifos nossos)

Se o poema é a forma pela qual os sentidos nos proporcionam ouvir o inaudito e ver o imperceptível, o tecer poético sobre as tapeçarias, feito pelas mãos de Maria Teresa Horta, nos proporciona múltiplos enredos e mistérios a serem (re)descobertos através das imagens de $L a$ Dame à la licorne que figuram por todo o livro.

A trama desenhada se complexifica quando a Dama ao passar, "com sua mão/ traça o mapa/ Usa a arma/o arco a seta o arpão", e, "parte em busca da aventura/ conquista e sedução/ por entre a trama tecida". Georges Bataille nos lembra que "essencialmente, o domínio do erotismo é o domínio da violência, o domínio da violação" (2014, p. 40) e que "toda operação erótica tem por princípio uma destruição da estrutura do ser fechado que é, no estado normal, um parceiro de jogo" (2014, p. 41). Na subversão do mito, Horta desloca a figura da Dama e a coloca como a caçadora: aquela que irá seduzir e capturar o Unicórnio, diferindo da posição social que esta ocuparia no imaginário medieval. Nesse sentido, a presença do erotismo simboliza uma subversão da ordem, da cultura e da sociedade; afinal, "o que está em jogo no erotismo é sempre uma dissolução das formas constituídas. Repito-o: dessas formas de vida social, regular, que fundam a ordem descontínua das individualidades definidas que somos" (2014, p. 42).

Ecoa nos nossos ouvidos os versos célebres camonianos: "Mudam-se os tempos, mudamse as vontades", pois é tempo de olhar para o passado e constatar a perda, a dor, a fratura que o feminino enfrentou por ser desejante e ter de silenciar os seus anseios. Sendo assim, não nos é gratuito que quando o livro se detém nas tapeçarias para descrevê-las comece por uma ordem não canônica, ou seja, é a sexta tapeçaria, aquela que congrega em si um enigma ainda não decifrado, mostrando-se como uma esfinge diante dos homens que a linguagem poética buscará desvendar ao abrir o grupo de poemas destinados «As tapeçarias». A transgressão da ordem aponta para o deslocamento do feminino em que o "reverso/ se revê no passado" onde a Dama ocupava a cena no imaginário medieval sobre o signo da pureza, da candura e da inocência passando para a posição de "senhora de si", dona do seu desejo, da sua fantasia, dos seus gestos e do seu gozo. 


\title{
À MON SEUL DÈSIR
}

\author{
A lenda A história \\ o tormento o afago \\ confissão de desejo \\ onde o poema fia \\ Os fios da tapeçaria \\ construindo o retrato da própria sedução
}

onde ela se desvia

À mon seul désir

diz a Dama tomando

nas mãos o direito

à sua fantasia

O gosto do corpo

em si mesmo provado

a dar conta do gozo

quando nele porfia

À mon seul désir

repete dobando

com a lã do afago

o prazer que ela tira

O gesto deslizante

pelo dentro cantado

volteando em si própria

com olhar da safira

À mon seul désir

desafiando o amado

dedos esvoaçados

onde a pele advinha

Ardilosa seduzindo

entre jogo e jogado

tomando o que pode

de si mesma rainha 
Maria Rita Kehl elucida: "todo sujeito é sujeito de um desejo, ou melhor, todo sujeito é sujeito porque é desejante" (1990, p. 368), e a Dama passa a se constituir de um sujeito no espaço textual, visto que agora há uma linguagem possível, uma dicção que lhe permite verbalizar as pulsões de Eros: a poesia. Entre o erotismo e a poesia não há uma disjunção, isto porque, como aponta Octavio Paz: "a relação entre erotismo e poesia é tal que se pode dizer, sem afetação, que o primeiro é uma poética corporal e a segunda uma erótica verbal" (1994, p. 12). Consciente do seu único desejo, a Dama passa a dar voz ao jogo da sedução, na medida em que "o cheiro das flores/ e o cheiro do corpo que/ desencadeia o desejo" e "do orgasmo/ e do grito/ do pudor já desfeito".

Do silêncio da repressão histórico-social ao grito do gozo, a escritura de Maria Teresa Horta trabalha o erotismo tanto na trama como na própria linguagem:

A linguagem - som que emite sentido, traço material que denota ideias corpóreas - é capaz de dar nome ao mais fugaz e evanescente: a sensação; por sua vez o erotismo não é mera sexualidade animal - é cerimônia, representação. O erotismo é sexualidade transfigurada: metáfora. A imaginação é o agente que move o ato erótico e o poético. É a potência que transfigura o sexo em cerimônia e rito e a linguagem em ritmo e metáfora. A linguagem poética é abraço de realidades opostas e a rima é cópula de sons; a poesia erotiza a linguagem e o mundo que ela própria, em seu modo de operação, já é erotismo. E da mesma forma o erotismo é uma metáfora da sexualidade animal. O que diz essa metáfora? Como todas as metáforas, designa algo que está além da realidade que lhe dá origem, algo novo e distinto dos termos que a compõem. (PAZ, 1994, p. 12, grifos nossos)

"A mão [da dama] a tentar/ desenredar o fogo que ao longo do corpo [do Unicórnio/ se encontra eriçado" cria um jogo de sedução em que ocorre uma caçada entre dois olhares: um “jogo arriscado e fascinante - angústia e gozo — onde o vencedor não sabe o que fazer do seu troféu e o perdedor só sabe que perdeu seu rumo: um jogo cuja única possibilidade de empate se chama amor" (KEHL, 1988, p. 411). "Primeiro são as rédeas/ os nós, o atropelo/ depois a Dama usa// o olhar emboscado// Os dedos à procura/ de alisar o pelo/ onde o Unicórnio// mais receia o afago". O objeto do desejo, o seduzido receia o toque, desconfia do jogo que está sendo jogado, mas a Dama ardilosa, por fim, consegue, por meio da "sedução/ convoca o enredo/ e ela desce a mão// no seu chifre alado".

Parece-nos que Maria Teresa Horta perverte, subverte e inverte a ordem das tapeçarias a serem retratadas, o que se afastaria do que aponta Cleonice Berardinelli. A posição das tapeçarias apresenta uma ordem em que o espectador pode percorrê-las através de uma gradação do menor para o maior (tato, paladar, olfato, audição, vista) ou pelo seu avesso (vista, ouvido, olfato, o gosto, o tato), mas que culmina na última tapeçaria denominada de Mon seul désir, o que, para a ensaísta, representa o "sentido interno, sediado no Coração, ou na Alma, nesse espaço bem 
mais abstrato, mais sentimento que sentido, voltado para essa Dama — sempre a mesma? capturável nas ordens em que parece apresentar-se através dos séculos" (BERARDINELLI, 2010, p. 150). Cabe, também, ressaltar a curiosa posição em que o poema "À mon seul désir" se encontra. Diferente dos demais 71 poemas que ocupam o espaço geográfico do livro, este, por retratar de forma irrefutável o desejo, o erotismo da Dama encontra-se escrito na vertical, sendo este o símbolo da ascensão e do progresso, mas que também nos aponta para a ereção, para o falo que, na cultura ocidental, representa a força do masculino. A Dama por ser agora a caçadora, a detentora do seu desejo e fantasia pode encontrar-se na posição vertical, pois é ela quem buscará domar o chifre daquele que vem a se tornar o objeto do seu desejo: o Unicórnio.

Em outro intervalo entre os quadros, abre-se uma fenda «reverso reverso» em que a figura do Unicórnio contempla a sua imagem diante do espelho ${ }^{4}$ (de Narciso?). "O que vemos só vale - só vive - em nossos olhos pelo que nos olha. Inelutável, porém é a cisão que separa dentro de nós o que vemos daquilo que nos olha" (DIDI-HUBERMAN, 2010, p. 29). Num movimento de verso-reverso, tanto o Unicórnio contempla a sua imagem refletida no espelho segurado pelas mãos da Dama, quanto a própria imagem o contempla:

cada coisa a ver, por mais exposta, por mais neutra de aparência que seja, torna-se inelutável quando uma perda suporta - ainda que pelo viés de uma simples associação de ideias, mas constrangedora, ou de um jogo de linguagem - e desse ponto nos olha, nos concerne, nos persegue. (DIDI-HUBERMAN, 2010, p. 33)

A imagem diante do espelho revela a incompletude do Unicórnio, pois há uma parte de si que lhe escapa, e o desejo amoroso configura-se como a perpétua sede de completude ${ }^{5}$ que busca o seu caminho através do jogo da sedução. O Unicórnio é um mito, é bipartido, um intermediário "como os anjos/ entre símbolo e olhar// a realidade e a magia". É aquele que espreita por entre os espinhos e avança aceitando as regras do jogo estipuladas pelo "gesto da Dama".

\footnotetext{
${ }^{4}$ Embora a figura do unicórnio esteja duplicada devido ao reflexo provocado pelo espelho nas mãos da Dama, é interessante atermo-nos a uma passagem descrita por Chevalier e Gheerbrant: "Em numerosas obras de arte, esculpidas ou pintadas, figuram dois unicórnios face a face, que parecem dar um ao outro combate feroz. Ver-seia nisso a imagem de um violento conflito interior entre os dois valores que o unicórnio simboliza: salvaguarda da virgindade (o chifre único levantado para o céu), e fecundidade (sentido fálico do chifre). O parto sem a defloração, esse poderia ser o desejo, contraditório no plano carnal, que se exprime pela imagem dos chifres em luta. O conflito só é superado, o unicórnio só se torna facundo e apaziguado, no nível das relações espirituais" (2009, p. 920).

${ }^{5}$ Enquanto que o mito do andrógino aponta para o fato de que todo homem e mulher busca a sua metade perdida, simbolicamente o unicórnio é, ao mesmo tempo, "o símbolo da virgindade psíquica. Alquimistas viam no unicórnio uma imagem do hermafrodita, o que parece ser um contra-senso: ao invés de reunir a dupla sexualidade, o unicórnio transcende a sexualidade. Tornara-se, na Idade Média, o símbolo da encarnação do Verbo de Deus no seio da Virgem Maria" (CHEVALIER \& GHEERBRANT, 2009, p. 919).
} 
Mon seul désir, diz a Dama a assumir para si a linguagem poética, a confessar no corpo textual a sua «alquimia»:

Eu capricho na conquista no fogo da sedução

Sou Dama da minha vida deixo nela a minha pista

Senhora do meu desejo de meu prazer e paixão

Jorge Fernandes da Silveira, ao analisar os poemas de Tatuagem, conjunto de três textos que integra Maria Teresa Horta no grupo de poetas de 61, aponta que a sua poesia "revela um contacto íntimo com o prazer do trabalho de criação" (1986, p. 184). É como se as palavras fossem armas de combate a qualquer tipo de censura. E, por isso, a Dama desobedece às ordens e inverte a sua posição nesta nova trama narrada/cantada por Horta, tomando "ao cavaleiro/ a sua montada". A Dama, tal qual o pequeno conjunto de poemas de 61 "se insubordina[m] contra a ordem das relações sociais e as formas de opressão na linguagem. Sintagmas partidos, e a consequente atomização de suas partes significativas, ficam a exigir um trabalho de «reparação» do leitor" (SILVEIRA, 1986, p. 183).

Em «Mon seul désir» não há mais espaço para uma fala de subordinação, anteriormente apresentada pelas tapeçarias e pelo imaginário medieval, pois a poesia de agora se configura como uma subversão (perversão?), através de uma linguagem que dá voz ao desejo, à paixão e ao gozo da mulher. A dicção adquirida instaura, no corpo poético, uma liberdade que permite que a figura da Dama seja "senhora de si", inscrevendo, reescrevendo uma outra significação na antiga ordem, de modo que o feminino possa ser deslocado, revisitado, dono do seu próprio desejo.

O caráter insubordinado dos poemas, a sua existência conceptual na linguagem e a fecundidade imagística; o corpo da mulher colonizado por relações sexuais e afectivas que transformam o amor e o prazer em estigmas da opressão; a construção de um espaço livre para a mulher e a sua maternidade; o erotismo do corpo e o prazer da linguagem contra o absolutismo de um único meio de expressão e o autoritarismo das formas mortas; a escrita como um acto revolucionário e um projecto de harmonia entre os sujeitos masculino e feminino; a proclamação, enfim, de um modo feminino de exercício do poder. (SILVEIRA, 1986, p. 195) 
A tenda ${ }^{6}$ que surge na sexta tapeçaria esconde, por debaixo de seu véu, a história pela qual o feminino foi vítima ao longo dos séculos. Em outras palavras, o ato de revisitação das tapeçarias promove a revelação das feridas ainda abertas, ainda sangrando no corpo da mulher. Os poemas de A dama e o unicórnio não escondem o passado; ao contrário, o resgatam para dentro do corpo textual para que este sirva de modelo, para que a insubordinação se erga através da linguagem, ao constatá-lo num enfrentamento capaz de deslocar a posição autoritária masculina em objeto de sedução onde a Dama é capaz de assumir a posição do cavaleiro.

\author{
A TENDA \\ A tenta A teia \\ À sombra da batalha \\ onde o sangue se esvai \\ e a penumbra erra \\ O tempo A tenda \\ À sombra do combate \\ do saque, do estupro \\ dos despojos da guerra \\ O templo A tenda \\ A ferida da espada \\ o exército, as tropas \\ a passar em revista \\ O topo A tenda
}

\footnotetext{
6 "Na sexta e última tapeçaria da célebre série do museu de Cluny intitulada $A$ dama com o unicórnio, a jovem mulher, que se despoja de suas joias, está prestes a ser absorvida pela tenda, símbolo da presença divina e da vacuidade. A inscrição que encima a tenda, um só desejo, significa que o desejo da criatura se confunde com o da vontade que a dirige. Na medida em que nossa existência é um jogo divino, nosso papel torna-se livre e ativo, quando nos identificamos com o manipulador de marionetes que nos cria e dirige. Então o ser particular dissolve-se para dar lugar ao grande Ser, sob a tenta cósmica ligada à estrela Polar. A Dama, por sua graça e sabedoria (Sofia - Xácti - Shekiná, isto é, a que está sob a tenda), assim como por sua pureza, pacifica os animais antagonistas da Grande Obra: o leão que simboliza o enxofre, e o unicórnio que representa o mercúrio. Com frequência a Dama é comparada ao Sal-filosofal. Está muito próxima da mentora de Hevajra, cujo nome significa aquela que não tem ego. O chifre erguido do unicórnio simboliza a fecundação espiritual e que capta o fluxo de energia universal e está de acordo com o simbolismo axial da tenda, prolongado por uma ponta com o simbolismo das duas lanças, com a dos penteados da dama e de sua acompanhante, encimados por enfeite de plumas, e com o das árvores que celebram o as núpcias místicas do Oriente e do Ocidente (o carvalho e o azevinho correspondendo à laranjeira e à jaqueira) [...] A ilha oval que sustenta a cena é recortada como um lótus, símbolo do desenvolvimento espiritual. Quanto ao pequeno macaco sentado diante da Dama, designa o próprio alquimista, o 'macaco por natureza', vigiando a sua senhora, que pode ser comparada à Prima Materia” (CHEVALIER \& GHEERBRANT, 2009, p. 920, grifos do autor).
} 


\author{
A mudar a mudança \\ onde a luz estando a Dama \\ já estremece imprecisa \\ A tenda A teia \\ De enredo dobado \\ lugar recolhido \\ em si mesmo um enigma \\ Ela entra, toma posse \\ e senta-se à lareira \\ Ou partirá em seguida \\ ela mesma à conquista?
}

Após o grito de liberdade proferido pela Dama, essa assume a palavra da sua própria história, ao dissolver a voz de alguém que, anteriormente, apenas narrava (cantava/recitava) o seu desejo ainda interdito, com os olhos de alguém seduzido pela imagem e trama; agora, no entanto, ela toma para si o lugar de sujeito do seu próprio desejo, ao dizer-se em primeira pessoa "Sou dona da minha vida", "Senhora do meu desejo". Sendo assim, o corpo e a ânsia do sujeito são transfigurados, através de um jogo sensorial e erótico, pelos poemas que, na sua urdidura, reconstroem imagisticamente o movimento sedutor do vento que revela o braço, desata os cabelos da aia, sobe-lhe a saia; faz entrever a nudez dos pulsos, da mão, a ponta do vestido que dobra as rosas, vestido este que se comportaria como uma armadura.

Contudo, consciente do ser desejante que é, a Dama "estremece", pois teme que os papeis tenham sido invertidos: de "mulher sedutora logo seduzida". Temendo encontrar-se na verdadeira condição do sujeito amado, ou seja, de escrava do objeto do seu anseio, ela duvida, se angustia, e "o desejo desliza/ num doce enleio com laço e fita". O Unicórnio, por sua vez, está à espera "dentro da mata", ele "aguarda", mantém-se assim no lugar do apaixonado, afinal "a identidade fatal do enamorado não é outra senão: sou aquele que espera" (BARTHES, 1981, p. 96). Quem espera é quem se vê enlaçado, amante, seduzido, preso num "tumulto de angústia suscitado pela espera do ser amado, no decorrer de mínimos atrasos" (BARTHES, 1981, p. 94). O jogo da sedução cria o ambiente perfeito para a perdição, onde o amante se faz amado e a vítima se faz caçador. Entre a Dama e o Unicórnio oscila a proposição desta escritura: “A dama seduz/ ou o Unicórnio entrega-se?"

O jogo da conquista mostra-se plural, oscila, mas a Dama persiste no ato, no gesto, na cena de sedução. Dentro do bosque incita o Unicórnio que a fita, o torna fraco, manso "a entregar-se", mas "recua" "temendo a avidez/ a crueldade, o ardil// delas desprendidos". Seduzido, entregue, o Unicórnio tem seu corno acariciado pela Dama, eis o «delito», pois se a Dama o captura, de símbolo e mito ele se materializa. E em «sigilo» confessa: 


\author{
Seduziste-me \\ Senhora \\ e eu deixei-me seduzir \\ de bom grado \\ No sigilo de vosso \\ colo \\ na devassa de vosso espelho
}

"Ele tem sangue de prata/ com o poder da eternidade"; assim é retratado o Unicórnio, o mito, o símbolo capaz de eternizar a Dama, a senhora de seu desejo. Entretanto, esta se vê solitária, e passa a questionar a sua eternidade, hesitando diante da vida, pois sabe que o feminino ainda revive a mesma história, o mesmo enredo, em que "para trás fica um imenso passado/ de irreparável solidão abismada/ feita de regras, de limites, de espaços/ fechados que definitivamente a algemam"; "Para trás fica um jogo armado em arremedo/.../ na conquista de uma liberdade que, na verdade a sequestra, a amestra, a doma e a sujeita". A Dama se apercebe como "lenda" e "saga" uma construção inventada pelas mãos de alguém que busca derrubar as arestas de um passado ainda presente. Vê-se "falsamente Dama do seu corpo/ a embrenhar-se na floresta da utopia em busca/ de um poder libertador daquilo que seria/ o seu inevitável destino sem gosto a futuro.”. Porém rebela-se, não renuncia a si própria nem a História para trás de si, e teima em embrenhar-se por entre as árvores, adentrando no bosque. "E ao ver-se agrilhoada ao Unicórnio/ ela entende o embuste, o passado/ que a rodeia e a leva a repetir-se/ numa infindável e incomensurável cadeia”. A Dama "peregrina, tal como Helena de Tróia/ foi um dia na Ilíada de Homero/ essa imensa e intocável epopeia/ onde a paixão e o ódio se digladiam".

Novamente pelas mãos de Jorge Fernandes da Silveira, tentamos uma interpretação. Ao debruçar-se sobre o retorno do épico, o ensaísta nos instiga e nos leva a acalmar o coração da Dama que tanto luta, insiste e persiste na busca por um lugar no tempo que a omite, a inscreve numa lenda. É pela fenda da poesia que essa Dama se multiplica, transgride, se comunica com outras mulheres de todos os tempos, pois

a interlocução entre versos [pode] ser lida como a construção de uma linguagem capaz de, em correspondências, dizer como em estado de censura, de proibição do livre trânsito da palavra, a poesia aprende a dizer, soletra, diz, e ensina a dizer, escreve o sentido de falar de liberdade em tempos de opressão, de fazer poemas como se fossem «notícias do bloqueio» por meio da troca de versos entre poetas ao mesmo tempo solitários e solidários com e por imagens. (SILVEIRA, 2010, p. 34)

Maria Lúcia Dal Farra comenta que a Dama se movimenta, pelas mãos de Maria Teresa Horta, por toda a tapeçaria, mas que ainda sim é presa pelo tecer da linha, da lã e da seda, 
como também da própria palavra poética. Contudo, Horta se apropria da tenture de La Dama à la licorne como um corpo a ser revisitado e como um corpus a ser tematizado. É através da união da arte com a poesia que será possível dar voz a um passado - por vezes silenciado - e por um presente, ainda em construção, referente ao feminino. Por meio da poesia, a Dama terá e poderá considerar-se a dona de seu corpo e de seus desejos, fazendo-se sujeito errante. Em outras palavras, “o discurso histórico não 'nasce' nunca. Sempre recomeça [...] A história da arte - a disciplina assim denominada - recomeça vez após outra. Toda vez ao que pareceu que seu próprio objeto é vivenciado como morto... e como renascendo" (DIDI-HUBERMAN, 2013, p. 13). Ao resgatar todo o imaginário medieval, percorrendo todas as seis tapeçarias, a autora de Tatuagem resgata as questões sócio-históricas pelas quais perpassa o corpo da mulher, buscando (re)visitar a dor, a fenda, as feridas, buscando uma linguagem, uma dicção possível, uma voz que passa a encontrar sua força no corpo da poesia:

\author{
AS VOZES \\ As vozes das mulheres \\ povoam cada uma \\ das tapeçarias \\ Mille-fleurs perecíveis \\ Invisíveis
}

Porém, a penúltima cena do livro corresponde a um conjunto de seis poemas sob o título «Uma fala sem mundo» em que a voz da Dama - cuja dicção ultrapassa a sua condição singular e atinge o coletivo feminino transcendendo as marcas histórico-temporais - passa a questionar-se sobre a sua eternidade. Todos os poemas deste grupo iniciam com o verso "O que faço da minha eternidade?" quase podemos ouvir o eco de Horta a questionar-se: «O que farei com estes versos»? E, talvez, respondemos: ficam na eternidade. A eternidade de uma busca por uma forma de traduzir a dor, o sofrimento e a violência que o corpo feminino sofre ao longo dos séculos. A escrita de Maria Teresa Horta, como bem exemplifica A dama e o unicórnio, busca combater a injustiça e soberania do exercício do poder patriarcal que ainda se instaura em nossa sociedade através do resgate das sombras por meio de uma fala que ainda tropeça na língua, gagueja, ensaia, mas que busca, através de uma dicção possível, a linguagem poética - forma capaz de transformar em contradiscurso a opressão e fazer do exercício poético uma função de libertação do feminino. Em outras palavras, tanto a Dama, quanto Horta, buscam cantar - mesmo com uma voz "enrouquecida" — para aqueles que não mais representam a "gente surda e endurecida" (Lus, X, 145, 4). Os versos que se desprendem das tapeçarias funcionam como uma 
quebra do silêncio sobre a violência [que] deve-se à presença, naquele que a promove, de um desejo de eliminar a profunda solidão motivada pela exclusão do humano — que se constitui pelo ato que marca a ruptura radical com o cotidiano que se arbitra como normal: "Aquele que fala, por mais cego que seja, conheceu, e duramente, a solidão a que a negação dos outros a condenava. Por seu lado, a violência é contrária a esta lealdade para com o outro que é a lógica, que é a lei, que é o princípio da linguagem". (BATAILLE apud PEREIRA, 2004, p. 34)

Numa fala sem mundo, ou num mundo ainda sem uma linguagem devidamente articulada, questiona-se a Dama sobre o seu discurso, sobre a sua eternidade, pois ainda há esperança para o canto que aqui se alevanta e atinge àqueles que são sensíveis à poesia. Consciente de si, do seu desejo e seu corpo, a Dama - e por que não Maria Teresa Horta? — nos diz(em):

O que faço da minha eternidade?

Pergunta de novo a si mesma

Enquanto impassível nos fita, imobiliza na trama armadilhada das tapeçarias

Com aquele travo mudo, com aquele brado surdo, com aquele olhar sem fundo

Numa fala sem mundo.

\section{Referências}

ABELAIRA, Augusto. O olfacto. In: SANTOS, Gilda; COSTA, Horácio (orgs.). Poética dos cinco sentidos revisitada. Rio de Janeiro: 7Letras, 2010. p. 27-31.

BARTHES, Roland. Fragmentos de um discurso amoroso. Rio de Janeiro: Francisco Alves, 1981.

BATAILLE, Georges. O erotismo. Belo Horizonte: Autêntica, 2014.

BERARDINELLI, Cleonice. Mon seul désir. In: SANTOS, Gilda; COSTA, Horácio (orgs.). Poética dos cinco sentidos revisitada. Rio de Janeiro: 7Letras, 2010. p. 148-154.

CAMÕES, Luís de. Os Lusíadas. Porto: Porto, 2009.

CHEVALIER, Jean; GHEERBRANT, Alain. Dicionário de símbolos, mitos, sonhos, costumes, gestos, formas, figuras, cores, números. São Paulo: J. Olympio, 2009.

DAL FARRA, Maria Lúcia. Novas cartas para as damas: leitura de A dama e o unicórnio, de Maria Teresa Horta e de Vozes, de Ana Luísa Amaral. Cadernos de Literatura Comparada, Porto, n. 35, p. 295-305, dez. 2016. Disponível em: https://ilc-cadernos.com/index.php/ cadernos/article/view/393/426. Acesso em: 22 nov. 2019.

DIDI-HUBERMAN, Georges. O que vemos o que nos olha. São Paulo: Editora 34, 2010.

. A imagem sobrevivente: história da arte e tempo dos fantasmas segundo Aby Warburg.

Rio de Janeiro: Contraponto, 2013. 
HORTA, Maria Teresa. A dama e o unicórnio. Lisboa: Dom Quixote, 2013.

IANELLI, Mariana. O mundo da dama e do unicórnio. Valor Econômico, São Paulo, 10 jan. 2014. Disponível em: https://www.valor.com.br/cultura/3390460/o-mundo-da-dama-e-dounicornio. Acesso em: 22 nov. 2019.

KEHL, Maria Rita. Masculino/feminino: o olhar da sedução. In: NOVAES, Adauto (org.). $O$ olhar. São Paulo: Companhia das Letras, 1988. p. 411-425.

O desejo da realidade. In: NOVAES, Adauto (org.). O desejo. São Paulo: Companhia das Letras, 1990. p. 363-383.

PAZ, Octavio. A dupla chama: amor e erotismo. São Paulo: Siciliano, 1994.

PEREIRA, Vitor Hugo Adler. A lei do silêncio da violência. In: DIAS, Ângela Maria; GLANADEL, Paula (orgs.). Estética da crueldade. Rio de Janeiro: Atlântica, 2004. p. 25-39.

SILVEIRA, Jorge Fernandes da. Portugal maio de poesia 61. Lisboa: Imprensa Nacional-Casa da Moeda, 1986.

$33-41,2010$.

O retorno do épico: a nau e a nave. Metamorfoses. Rio de Janeiro, v. 10, n. 2, p.

\section{Minicurrículo}

Carlos Roberto dos Santos Menezes é doutorando do Programa de Pós-graduação em Letras Vernáculas (PPGLV) na área de concentração destinada à Literatura Portuguesa pela Universidade Federal do Rio de Janeiro (UFRJ). Mestre em Letras Vernáculas no (PPGLV) em Literatura Portuguesa pela UFRJ. Ex-bolsista júnior do Real Gabinete Português de Leitura em parceria com a Fundação Calouste Gulbenkian com o projeto "Diálogos intranarrativos a propósito dos romances de Augusto Abelaira” (2017). 